Article

\title{
Impact of Ambidexterity and Environmental Dynamism on Dynamic Capability Development Trade-Offs
}

\author{
Michael Yao-Ping Peng ${ }^{1}$ and Ku-Ho Lin ${ }^{2, *(1)}$ \\ 1 School of Economics and Management, Xi'an University of Posts \& Telecommunications, Xi'an 710121, \\ China; s91370001@mail2000.com.tw \\ 2 Department of Administration Business, National Chung Hsing University, Taichuang 402, Taiwan \\ * Correspondence: link@dragon.nchu.edu.tw; Tel.: +886-939252426
}

Received: 16 March 2019; Accepted: 15 April 2019; Published: 18 April 2019

\begin{abstract}
Based on the dynamic capabilities view, this study first examines whether the co-existence of explorative and exploitative capabilities can directly cause organizational tensions. In addition, this study employs the combination of these two capabilities to examine how organizational ambidexterity affects organizational tensions. The research subjects consisted of high-tech firms in Taiwan developing new, high-tech products, and a total of 154 valid questionnaires were returned from these. A hierarchical multiple regression model was used for hypotheses testing. Our findings show that explorative capability is not statistically significant, but that exploitative capability significantly and positively influences organizational tensions. This study provides support for the strong moderating effect of environmental dynamism on the relationship between organizational ambidexterity and organizational tensions.
\end{abstract}

Keywords: ambidexterity; dynamic capability; organizational tensions; environmental dynamism

\section{Introduction}

In the past two decades, Taiwanese firms in high-tech industries (e.g., telecommunications, computer hardware and software, semiconductors, electronics, biotechnology, medical, and pharmaceuticals), have often held a dominant market position based on superior Research and Development (R\&D) and innovation [1,2]. The Taiwanese high-tech industry has maintained its current long-term competitive position by investing in $R \& D$, as well as advanced manufacturing techniques. Several science parks have been constructed in different regions of Taiwan, such as the Neihu, Hsinchu, Central, and Southern science industrial parks, which provide an important resource network for new technology-based enterprises [2]. Because of the increasing importance of emerging foreign markets and global competition, such high-tech firms should devote more efforts to enhancing critical capabilities [3-5] in order to implement new product development and marketing, with major partners in different countries or niche markets [6].

Scholars have discussed how firms can apply and enhance their core capabilities to create competitive advantages from the perspective of dynamic capabilities (DCs) [7-9]. DCs emphasize the appropriate adaptation, integration, and reconfiguration of an enterprise's strategies and internal as well as external skills and resources, so that they are attuned to changes in the environment. Zott [10] pointed out that even a very small difference between the DCs of firms will lead to a divergence in those firms' performance; this was also supported by the research results of Helfat and Peteraf [3] and O'Reilly and Tushman [11]. Fainshmidt, Pezeshkan, Frazier, Nair and Markowski [12] integrated previous DC studies, and indicated that although various studies have conceptualized the DC construct 
by measuring different variables, most of these variables have been comprehensively discussed in relation to explorative and exploitative capabilities [3,8,13-16].

Based on extant literature, this study aims to address three critical knowledge gaps. First, few studies have explored the negative effect of DCs from the "dark-side" issue [17]. Because of a lack of resources and restricted scope of management, explorative and exploitative capabilities have often been viewed as having a trade-off relationship, rather than being complementary $[13,18]$. Here, a trade-off means that firms should either enhance existing abilities or focus on developing new ones [19]. Although most studies have emphasized the positive influence of explorative or exploitative capability on performance, few have examined whether and how issues related to trade-offs can be solved in this context.

When the organization cannot achieve a balance between the two capabilities, organizational tension is likely to arise. According to the tension-based view, an unbalanced trade-off relationship also gives rise to tension. Conflicting forces within organizations are often hidden, and pull one another, eventually leading to organizational instability [20,21]. Fainshmidt et al. [12] stated that in industries with high technological dynamics, DCs must be fully used and developed, as these firms must have DCs in order to mitigate the unpredictability of results [3,5]. However, this is based on the premise that the investment cost of resources should be increased; indeed, resource allocation in relation to DCs is also a difficult issue [22,23]. Therefore, organizations must understand the relationship between tension and capabilities. While the firm performance is discussed, the discussion on issues related to enterprise growth and survival is also required. When the enterprise has different opinions on the use of resources, the sustainability of enterprise growth and survival may be affected. Organizational ambidexterity creates a context in which different perspectives are combined, and this produces the complementarity. In addition to strengthening the sustainability of enterprise growth, it also generates sustainable competitive advantages.

Moreover, organizational ambidexterity can not only reduce internal tensions, but it also maintains the mutual support of internal capabilities, thus providing a kinetic energy with continuous and steady development.

Second, the need for an appropriate balance between exploration and exploitation has been emphasized by Tushman and O'Reilly's [24] concept of ambidexterity [18,25-33]. Many related studies have emphasized the simultaneity of explorative and exploitative activities, and defined ambidexterity as combining these in ways that impact firm performance $[16,18,26,34]$. However, these studies have left a critical gap in terms of whether negative factors (organizational tensions) within the organization will disappear even if ambidexterity has improved organizational performance $[18,24,28,35]$. This study explores whether ambidextrous firms can reduce organizational tensions based on a context.

Third, extant literature on exploitation and exploration $[13,35]$ has failed to explore the roles played by environmental context. Scholars have only recently started exploring how environmental [26,31] and organizational [25,32] moderators affect interrelations among ambidexterity, its antecedents, and performance outcomes [27]. Environmental transformation will strongly lead firms to adapt or update existing capabilities to address market demands, which means that environmental dynamism is regarded as an important factor [36,37]. However, little is known about how certain aspects of environmental dynamism moderate the effects of capabilities and ambidexterity on tensions, especially in high-tech firms. The current study thus focuses on the environmental dynamism that facilitates the effects of organizational ambidexterity on tensions.

\section{Literature Review and Hypotheses Development}

\subsection{The Dynamic Capability and Tensions-Based View}

Two main theoretical foundations contribute to this study: The DC approach, and the tension-based view. Regarding the former, Helfat and Peteraf [3] defined DCs as a firm's processes that use resources—specifically, processes to integrate, reconfigure, gain and release resources— to match and 
even create market change" and "organizational and strategic routines by which firms achieve new resources and configurations as markets emerge, collide, split, evolve, and die.

Through these processes, firms constantly integrate, reconfigure, renew, and recreate resources and capabilities in response to the changing environment, in order to attain and sustain a competitive advantage $[8,9,38-40]$.

Most related studies $[8,38]$ have agreed that the development of capabilities can establish or strengthen an enterprise's competitive advantage in a turbulent environment. According to the knowledge-based view, knowledge, which is abstract, can only be transferred via the active involvement of knowledge disseminators; in the process of learning, capability, far from being improved in the form of non-standardized specific knowledge in any subject, provides an integration mechanism [21,41-43]. Zollo and Winter [5] stated that the organizational capability should be emphasized when the integration of external knowledge and information is discussed. Additionally, considering the time needed to develop such capabilities, and the fact that the results of learning process are often highly idiosyncratic, managers must decide which capabilities to develop and invest in, and then establish strategies therefor [39]. Consequently, management decisions about which capabilities to develop, separately or concurrently, are also strategic decisions. In addition to this, we alter external skills and resources so that they are attuned with changes in the environment. Fainshmidt et al. [12] integrated past-related research about the ambidexterity of two DCs, showing that the relevance of organizational performance discussed in relation to the high-order DC was stronger than that discussed in relation to the low-order DCs, which meant that DCs were composed of different types of measured variables. Conversely, the majority of studies have been focused on the exploitation capability and the exploration capability $[11,18]$.

The essence of explorative capability emphasizes the generation of new perceptions and ideas, or the variation of existing ones, and the selection of the most appropriate perceptions and ideas via assessment processes [44]. Conversely, exploitative capability involves activities such as path-dependent learning and knowledge storage. Firms tend to stress the development of existing markets, rather than extending to new ones, until they accumulate adequate capabilities [14]. The current study employs the DC view to explain the trade-off relationship between explorative and exploitative capabilities, and the effect this has on organizational tensions. Several hypotheses are suggested.

Regarding the tension-based view, though explorative and exploitative capabilities automatically transfer the related efforts into superior performance [16], this does not mean the respective firm can overcome, integrate, or reduce existing contradiction and conflict. This point represents a gap in the literature, since previous studies have failed to consider such "dark-side issues." Raisch, Birkinshaw, Probst, and Tushman [45] claimed that companies have their own favor when allocating limited resources; thus, they pull from both ends of the explorative and exploitative continuum, and thereby cause organizational tensions to arise [18,28]. Raisch et al. [45] also put forward other relevant internal organizational tensions, such as efficiency, flexibility, differentiation and low-cost strategy, as well as global integration and local response, which can be summarized as alignment and adaptability [28]. The present study discusses the relationship between explorative and exploitative capabilities on DCs; this is in line with the exploratory research conducted by Andriopoulos and Lewis [46], who divided the tensions into (1) strategic intent (profit emphasis vs. breakthrough emphasis) as a firm's reason for being, and (2) related tensions arising from the need to emphasize both profit and breakthroughs. Customer orientation (tight coupling vs. loose coupling) attaches much importance to activities that help explain customer demands, needs, and behaviors. Personal drivers refer to employees' personality traits, which can be broadly divided into discipline and passion.

\subsection{The Direct Effects of Explorative Capabilities on Organizational Tensions}

Previous studies have stated that explorative and exploitative capabilities are closely bound to organizational survival and growth $[13,35]$. Although explorative and exploitative capabilities automatically transfer related efforts into superior performance [16], firms cannot necessarily overcome, 
integrate, or reduce existing trade-off issues. A research gap exists in this area, because few studies have considered the negative effect of an imbalanced development of capabilities.

In terms of strategic intent, firms that place a greater emphasis on breakthroughs must take certain risks when searching for new opportunities that may enhance the firm's reputation and adaptability [46]. We thus argue that Taiwanese high-tech firms are dedicated to certain explorations, since they face enormous pressure to catch up in terms of $R \& D$ in order to prevent their products from immediately becoming obsolete. Furthermore, out-of-date products have the potential to create serious inventory problems [9], which further enhance tensions. Moreover, in customer orientation, being loosely coupled is conducive to the exploration of new products or technologies, thus enabling the firm to identify and exploit future opportunities. However, a likely result of any overdeveloped abilities for exploring new opportunities or markets, is the predominantly projects-driven approach adopted by future-oriented firms; these firms can in turn lack clear targets and become wasteful. Continuously seeking blue-sky possibilities can create "opportunity traps" that ignore market demands [47].

With regard to personal drivers, passion-driven employees seek high individual performance, explorative activities, and challenges, and the firm can stimulate the creativity of its knowledge workers by increasing these motivations [46]. While continuing technological advances have moved the Taiwanese economic structure from a labor-intensive to a more technology- and capital-intensive marketplace, high-tech employees are becoming increasingly exposed to stressful Western and industrialized work situations [48]. Development of explorative capabilities often belongs to long-term orientation, such as after a new product appears, it will experience the initial stages of a product life cycle, and new product operational performance cannot defray operating cost $[43,46,49]$. If firms seldom engage in exploitive capability or activity concerning organizational survival (threshold capabilities, consolidated capabilities, refining or expanding existing capabilities, technologies and models), it may reduce their survival chances [14]. While firms engaged in explorative process take advantage of expenditures or resources that originally belong to exploitive process, organizational tensions will be enhanced [18]. Therefore, we hypothesize:

H1a. There is a positive relationship between explorative capabilities and organizational tension.

\subsection{The Direct Effects of Exploitative Capabilities on Organizational Tensions}

Contrastingly, numerous firms that emphasize profits seem to be infused with the spirit of conservatism, and stress the value of repeat clients and efficiency. Moreover, they tend to focus on the development of exploitative capabilities [46]. On the other hand, we argue that firms may fail to prevent their products from immediately becoming obsolete if they are dedicated to certain exploitations with regard to catching up regarding R\&D. Because out-of-date products can create serious inventory problems [9], such obsolescence causes further imbalanced tensions.

Tight coupling to the customer can be either a blessing or a curse; and although it often provides insights into the current market, and yields higher customer satisfaction and loyalty [50,51], it makes exploring new products or technologies difficult, such that firms can fail to identify and exploit future opportunities. Moreover, tight coupling costs relatively more compared to loose coupling with regard to maintaining customer relationships; firms can't access more customers, obtain increased nonreplicated information, and explore new opportunities to expand knowledge. In Taiwan's high-tech industry, most companies (with the exception of Acer, ASUS, HTC, and other terminal firms), are component suppliers. In the process of developing explorative capabilities, these suppliers often maintain close customer-oriented relationships [52]. In addition to incurring additional costs for relationship maintenance, and spending most of their energy in meeting customer demands, they indirectly isolate potential customers and new markets, leading to a lock-in effect.

If staff are discipline-driven, they work in accordance with the development process, the target, and the roles defined by the firm to perform organizational tasks. Discipline-oriented workers engage in repetitive activities embedded in standardized best practices, rather than aiming to increase the 
speed and efficiency of innovation [53]. Excessive standardization may engender alienation and rigidity [54], while overly-obsessed individuals may cause inefficiency.

Therefore, excessive emphasis on either discipline leads staff to engage in a single explorative or exploitative activity, which implies increased tensions. Therefore, we hypothesize:

H1b. There is a positive relationship between exploitative capabilities and organizational tension.

\subsection{The Effect of Organizational Ambidexterity on Organizational Tensions}

When organizations face basic problems, they devote themselves to using adequate exploitative capabilities to ensure current viability. However, organizational energy should also be allocated to explorative capabilities to ensure future viability [13]. Explorative and exploitative capabilities are effective accelerators for growing organizational performance. Exploitative activities can enhance the reliability and productivity of organizations in several areas, whereas explorative activities can enhance organizational abilities to add new knowledge to the original knowledge stock, thereby enabling the organization to create new products and services to meet new market demands [35]. However, market conditions and resource limitations can result in organizations failing to pursue both at the same time, lest they get "stuck in the middle." In a strategic study of 300 small enterprises, Ebben and Johnson [55] found that firms trying to pursue both efficiency and flexibility had lower performance than did those using a single and concentrated strategy. However, some scholars believe that using single, effective strategies can work only in the short term, until the firm can no longer make any progress [56].

Gibson and Birkinshaw [28] referred to Tushman and O'Reilly's [15] findings regarding ambidexterity, using the metaphor of a juggler to describe an ambidextrous organization's varied goals of lower costs, greater efficiency, and incremental innovation in mature markets. Zhan and Chen [16] defined ambidexterity as the "simultaneous pursuit of both exploration and exploitation via loosely-coupled and differentiated subunits or individuals, each of which specializes in either exploration or exploitation" (p. 610). However, ambidextrous organizations conduct inspections and other activities with speed and flexibility in emerging markets to develop new products or services [46]. Gibson and Birkinshaw [28] proposed four features of ambidextrous individuals that can enable firms to fully implement organizational ambidexterity: (a) They take the initiative, and are alert to opportunities beyond the confines of their jobs; (b) they are cooperative, and seek opportunities to combine their efforts with others; (c) they are brokers, who are always looking to build internal linkages; and (d) they are multitaskers, that are comfortable wearing multiple "hats." Although managing these+ trade-offs frequently presents nontrivial organizational challenges, the ability to reconcile and harness these trade-offs can enable firms to effectively improve performance [28,44]. For example, when Microsoft marketed its Windows 8 operating system, its top priority was marketing to all consumers. Understanding users' habits, opinions and feedback, and improving the operating fluency of personal computers through internal processes, are the main profit sources of the company. On the other hand, establishing specific project teams to develop a new interface, Windows 10, and other information technology applications, is regarded as a potential future profit source.

Following the cooperative approach, the two views with their different orientations have a competitive relationship, but can produce mutual support and help each other leverage the use of resources, which may be called combined ambidexterity $[18,26]$. Via repeated usage of existing knowledge and resources, managers can detect these within the firm more easily, and understand them more thoroughly, thereby reconfiguring existing knowledge and resources (exploitation), and promoting the capability to develop new products and markets (exploration) [41]. There are several studies dealing with capabilities in the knowledge-based development, and especially in the complementarity of various knowledge [41-43]. They reveal the dynamic nature of capabilities in knowledge-based development, and emphasize that the combination of knowledge and capabilities generate competitive advantages [43]. Andriopoulos and Lewis [46] indicated that combined ambidexterity can be regarded as contextual ambidexterity, emphasizing two activities with mutual dependence, and that this 
combination can be used to effectively manage tension factors such as strategic intention, customer orientation, and personal drivers.

For example, organizations with contextual ambidexterity stress the synergy between profit breakthroughs and strategic intention, devoting themselves to fostering a paradoxical vision. This is because when firms internalize external knowledge and resources by using their explorative capabilities, they can extend their own competences, so that more effective routines and processes are utilized in larger economies of scale. Andriopoulos and Lewis [46] pointed out that ambidexterity, through a differentiation strategy [15], encourages firms to develop different structures to deal with the activities of conflicts and contradictions in order to reduce organizational tension. For example, according to different strategic objectives, firms use rich conventions, profitable cases, and high-risk, breakthrough projects to diversify their portfolios, so that they can leverage existing strengths and accept the risks involved in accessing future market opportunities [57].

However, regarding customer orientation, we emphasize a synergy between existing routines and the limitations of knowledge, as well as the exploration of new opportunities, as indicated by the form of improvisation described by Miner et al. [47]. Existing knowledge and routines can be restructured to connect appropriate ideas to meet new demands at the right time [58]. In the context of personal drivers, characteristics of socialization, which combine discipline and enthusiasm, are helpful for encouraging staff to regard themselves as practical artists. Taiwanese high-tech firms invest significant amounts in $R \& D$ and capital expenditure. If they can simultaneously develop their exploitative and explorative capabilities, and seek to balance the allocation of management attention and resources between these two capabilities, then they are more likely to obtain good results in terms of commercializing new technologies, as well as reducing tensions [59]. Therefore, we hypothesize:

H2. The firms' ambidexterity will have a negative effect on its organizational tension.

\subsection{The Moderating Effect of Environmental Dynamism}

The effects of external environment on organizational capabilities and performance have been widely studied $[25,35]$. Although the dynamic capability literature has emphasized the antecedents, components, and consequences of such organizational capabilities [40], less attention has been paid to the environmental contexts that affect how organizations deploy their DCs to reduce tensions. Environmental dynamism refers to the rate of change, the absence of patterns, and the unpredictability of the external environment. Dynamic environments are characterized by changes in technologies, variations in customer preferences, and fluctuations in product demand or supply of materials [31]. With the notable exception of Helfat and Peteraf [3], DC theories have suggested that environmental dynamism could be a determinant of the appropriate application of the DC construct.

Higher environmental dynamism refers to greater environmental uncertainty; according to the transaction cost view, firms lack sufficient adaptation to develop specific capabilities that influence decision making, regarding resource allocation [60]. When environmental dynamism is high, DCs make a greater contribution, enabling firms to extend, change, and create resources, and providing a foundation and set of routines to ensure companies can change their entire operation [61]. However, performing explorative and exploitative capabilities simultaneously costs more than does developing a single ambidextrous capability. Whether organizational ambidexterity favors organizational effectiveness and efficiency, and reduces organizational tensions, depends on the situation at hand [52]. In the long term, along with the gradual collapse of the stable markets regime [53], firms tend to focus on the development of exploitative capabilities in path-dependent conditions, which may produce competence traps [35] and lead to core rigidity and increased organizational tensions. The Mpinganjira et al. [60] study also indicated that firms confronted with substantial external uncertainty respond to the adaptation problem by establishing specific interorganizational arrangements, wherein the introduction of such internal conflict may enforce tensions.

In a dynamic environment, where customer demand, buyer-seller relationships, and competitor activities change continually, the firm must coordinate the development of capabilities in order to be 
flexible and efficient. Moreover, in competitive environments, high-tech firms may not focus only on enhancing the scale and scope of knowledge integration, but also on enhancing their efficiency of knowledge utilization [31].

Firms with greater ambidexterity that operate in dynamically competitive environments can more effectively deploy resources in a balanced manner for the development of various abilities or activities [62], thereby lowering organizational tensions [63]. Given the high degree of novelty that high-tech firms operating in highly dynamic environments are likely to face, which gives rise to organizational tensions, matching appropriate routines to these novel settings (creating an ambidextrous context) will prove challenging (i.e., these firms face a matching problem). Similarly, Zhan and Chen [16] suggested that firms which work to explore or upgrade their sources of competitive advantage in response to environmental dynamics will have greater operational flexibility. Therefore, we hypothesize:

H3. Environmental dynamism negatively moderates the relationship between organizational ambidexterity and organizational tensions.

Building on the preceding contributions, Figure 1 presents our conceptual model.

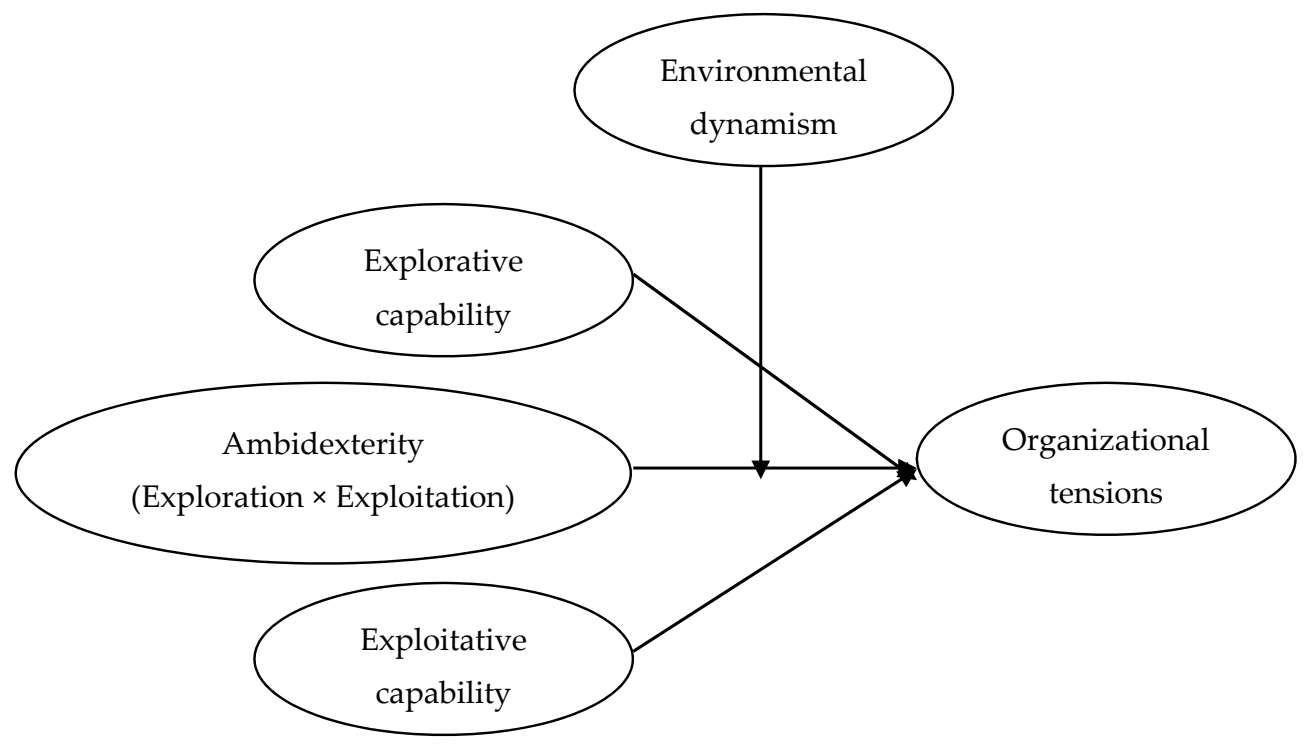

Figure 1. Research framework.

\section{Methodology}

\subsection{Sampling and Data Collection Procedures}

This study first modified scales developed in previous studies to conform to its research goals. A total of 30 managers at firms in Taiwan were selected as subjects of the questionnaire pretest. The recovered pretest questionnaires were used to confirm the appropriateness of the wording, and test reliability and validity; the formal questionnaire was then compiled after deleting inappropriate items. The database of the Taiwan Association of Industries in Science Parks was used to create a sample list, which was filtered by industrial classification. To test the hypotheses, we employed Taiwan's high-tech firms, and surveyed the informants' (CEOs', vice presidents', and senior managers') knowledge about, and responsibilities related to, their companies. These top managers were selected because they have mastered most of their companies' business tasks [64] and are familiar with actual situations of internationalization, capability development, and operations. We sent out 500 questionnaires, and received 163 completed responses, giving a 32.5\% response rate. After eliminating nine invalid questionnaires, 154 valid ones remained, giving a 30.8\% effective response rate. 
To confirm whether there were differences in the responses between two firm sizes, the present study conducted a non-response deviation test. Several independent-samples $\mathrm{T}$ tests were conducted to test the null hypothesis that the means of the answers across these two firm sizes were the same. The results of this test show that there were no significant differences in the basic data of the main aspects, which means that there were no significant differences between the sample data of two firm sizes.

\subsection{Assessment of Variables}

The questionnaire variables were chiefly developed from scales available in previous works. Except for firm size and firm age, all questions were answered using a seven-point Likert scale. The five questions on the explorative capability scale and four questions on the exploitative capability scale were taken from He and Wong [18], Lubatkin et al. [32], Menguc and Auh [65], and Cao et al. [27]. We asked respondents to state the extent to which their firms had used each exploitative and explorative activity in the last three years on a seven-point Likert scale ( $1=$ strongly agree; $7=$ strongly disagree).

Following He and Wong [18] and Menguc and Auh [65], the concept of ambidexterity used in this work follows the theoretical conceptualization of ambidexterity in the literature [15]. Cao et al. [27] and He and Wong [18] proposed two methods of computing ambidexterity; namely, combined dimension of ambidexterity (CD ambidexterity), and balanced dimension of ambidexterity (BD ambidexterity). $\mathrm{CD}$ ambidexterity is the product of the scores of explorative and exploitative capabilities. The higher the score is, the higher the degree of $\mathrm{CD}$ ambidexterity will be. BD ambidexterity is the absolute value of the difference between the scores of explorative and exploitative capabilities. When the score is closer to 0 , it represents that the degree of $\mathrm{BD}$ ambidexterity is higher. However, there is an error in the calculation of BD ambidexterity; namely, when both the explorative and exploitative capabilities score low in this regard, the degree of ambidexterity is higher. Furthermore, Junni et al. [49] pointed out that adopting the computational method of $C D$ ambidexterity will indicate higher performance, and is conducive to applying a cross-sectional study design, which is an interaction term (explorative capabilities $\times$ exploitative capabilities). Since ambidexterity was measured by multiplying the explorative and exploitative capability constructs, we acknowledge that it may suffer from multicollinearity. To minimize this concern, we mean-centered the constructs of explorative and exploitative capabilities before deriving the degree of ambidexterity [66].

Organizational tension refers to a set of two contradictory forces with conflicting goals that exist in an organization. Following Andriopoulos and Lewis [46], Groysberg and Lee [67], and Jansen et al. [30], three dimensions were used to construct organizational tensions: Strategic intent, customer orientation, and personal drivers, with four items for strategic intent, three for customer orientation, and another four for personal drivers. Organizational tension was measured using binominal semantic differential scales, as the end points consist of two bipolar activities assigned values of 1 and 7 , respectively [68]. This study used the binominal scale to understand whether the relationship tensions within organizations are balanced or imbalanced; for example, relationship orientation versus transaction orientation, and one item of customer orientation, with questions scored from 1 (extreme relationship orientation) to 7 (extreme transaction orientation). When the score is closer to 1 or 7 , the internal organizational tension is higher; relatively, when the score is closer to the median value of 4 , the tension is lower.

Environmental dynamism refers to the volatility and unpredictability of the firm's external environment. To capture dynamism, we used six items developed by Jaworski and Kohli [69] and Atuahene-Gima [25].

We controlled two variables that might affect the model: Firm size and firm age. According to the Resource-based view (RBV), size has a positive effect on resource allocation, and was used as a control variable. Size is expressed as the firm's number of employees. Furthermore, because firm age denotes a firm's development stage regarding the acquisition of new knowledge and technology, and is associated with the development of explorative and exploitive capabilities $[27,70]$, this attribute was also one of the control variables. 


\section{Results and Analysis}

\subsection{Reliability and Validity}

The descriptive statistics for the scales are summarized in Tables 1 and 2. Confirmatory factor analysis and LISREL 8.54 were used to measure the reliability and validity of the scale. The construct validity of the scale was verified concerning convergent and discriminant validity. According to Hair, Black, Babin, Anderson, and Tatham [71], the evaluation standards for convergent validity are (1) the standardized factor loading should be greater than $0.5,(2)$ average variance extracted (AVE) should be larger than 0.5 , and (3) composite reliability (CR) should be higher than 0.7 . The evaluation standard for discriminant validity is that the square root of the AVE for one dimension should be greater than its correlation coefficient with any other dimension.

Table 1 shows that the AVE for all dimensions exceeds the threshold value of 0.5 , with all CR values larger than 0.7. As suggested above, all items in measures of exogenous variables can be significantly explained by this factor; i.e., all items converge to this factor, which means that all items converge to their corresponding dimensions. Therefore, the scale has some convergent validity. Finally, the results in Table 2 show that the correlation coefficients of dimensions are all less than the square root of the AVE, proving that each dimension in this study has good discriminant validity.

Table 1. Descriptive Statistics.

\begin{tabular}{|c|c|c|}
\hline Construct & Variables and Items & Factor Loading \\
\hline \multirow{6}{*}{ Explorative capability } & Explorative capability $(\mathrm{AVE}=0.74, \mathrm{CR}=0.94)$ & \\
\hline & Introduce new generation of products & 0.759 \\
\hline & Extend product range & 0.780 \\
\hline & Open up new markets & 0.935 \\
\hline & Enter new technology fields & 0.888 \\
\hline & Innovations in marketing techniques & 0.930 \\
\hline \multirow{5}{*}{ Exploitative capability } & Exploitative capability $(\mathrm{AVE}=0.61, \mathrm{CR}=0.86)$ & \\
\hline & Improve existing product quality & 0.632 \\
\hline & Improve production flexibility & 0.780 \\
\hline & Reduce production cost & 0.776 \\
\hline & Improve yield or reduce material consumption & 0.900 \\
\hline \multirow{15}{*}{ Organizational Tensions } & Strategic intent $(\mathrm{AVE}=0.59, \mathrm{CR}=0.85)$ & \\
\hline & Repeatability and Predictable Behavior vs. Highly & 0.656 \\
\hline & Creative Behavior & \\
\hline & Short-term Orientation vs. Long-term Orientation & 0.720 \\
\hline & Risk-Avoiding vs. Risk-taking & 0.828 \\
\hline & High Stabilization vs. High Unpredictable Tolerance & 0.849 \\
\hline & Customer orientation $(\mathrm{AVE}=0.58, \mathrm{CR}=0.80)$ & \\
\hline & $\begin{array}{l}\text { Fosters client satisfaction and loyalty vs. Probing new } \\
\text { products/technologies surfaces future opportunities }\end{array}$ & 0.732 \\
\hline & $\begin{array}{l}\text { Meeting existing customers' demands vs. Opportunities of } \\
\text { developing new customers }\end{array}$ & 0.785 \\
\hline & $\begin{array}{l}\text { Clients' requirements help projects fulfill market needs vs. } \\
\text { Ongoing experimentation extends firm knowledge base }\end{array}$ & 0.762 \\
\hline & Personal drivers $(\mathrm{AVE}=0.66, \mathrm{CR}=0.88)$ & \\
\hline & $\begin{array}{l}\text { Autonomy and independent activity vs. Highly cooperative, } \\
\text { interdependent behavior }\end{array}$ & 0.839 \\
\hline & Obedience quality vs. Creativity quality & 0.694 \\
\hline & Tight control vs. loose control & 0.805 \\
\hline & Specific individual or group goal vs. general goal & 0.892 \\
\hline \multirow{7}{*}{ Environmental dynamism } & Environmental dynamism $(\mathrm{AVE}=0.66, \mathrm{CR}=0.921)$ & \\
\hline & Competition in our industry is cutthroat & 0.824 \\
\hline & There are many promotion wars in our industry & 0.777 \\
\hline & Price competition is a hallmark of our industry & 0.849 \\
\hline & $\begin{array}{l}\text { In our kind of business, customers' preferences change quite a bit } \\
\text { over time }\end{array}$ & 0.740 \\
\hline & Our customers tend to look for new product all the time & 0.815 \\
\hline & $\begin{array}{l}\text { We are witnessing demand for our products and services from } \\
\text { customers who never bought them before }\end{array}$ & 0.868 \\
\hline
\end{tabular}


Table 2. Measurement.

\begin{tabular}{|c|c|c|c|c|c|c|c|c|c|c|c|}
\hline Measure & Means & SD & 1 & 2 & 3 & 4 & 5 & 6 & 7 & 8 & 9 \\
\hline 1. Explorative & 4.93 & 1.15 & $(0.860)$ & & & & & & & & \\
\hline 2. Exploitative & 4.93 & 1.11 & $0.688^{* *}$ & $(0.781)$ & & & & & & & \\
\hline 3. Environmental dynamism & 5.35 & 0.95 & $0.372 * *$ & $0.275^{* *}$ & $(0.812)$ & & & & & & \\
\hline 4. Strategic intent & 4.76 & 0.95 & $0.393^{* *}$ & $0.400^{* *}$ & $0.751^{* *}$ & $(0.768)$ & & & & & \\
\hline 5. customer orientation & 4.83 & 1.06 & $0.275^{* *}$ & $0.371^{* *}$ & $0.584^{* *}$ & $0.724^{* *}$ & $(0.762)$ & & & & \\
\hline 6. Personal driver & 4.78 & 0.93 & $0.325 * *$ & $0.435^{* *}$ & $0.510^{* *}$ & $0.636^{* *}$ & $0.734^{* *}$ & $(0.812)$ & & & \\
\hline 7. Ambidexterity & 0.68 & 1.35 & $-0.319^{* *}$ & $-0.387^{* *}$ & -0.066 & -0.117 & -0.044 & -0.032 & - & & \\
\hline 8. Firm size & 2.57 & 1.45 & 0.143 & $0.193^{* *}$ & 0.043 & 0.028 & 0.050 & 0.110 & -0.103 & - & \\
\hline 9. Firm age & 3.32 & 1.11 & -0.109 & 0.132 & 0.002 & 0.004 & 0.005 & $0.220 * *$ & 0.001 & $0.458^{* *}$ & - \\
\hline
\end{tabular}




\subsection{Hypotheses Testing}

When self-report questionnaires are used to collect data at the same time from the same participants, common method variance may be a concern. Following Podsakoff et al. [72], we included in the partial least squares (PLS) model a common method factor whose indicators included all the principal constructs' indicators, and calculated each indicator's variances substantively explained by the principal construct and by the method. The results demonstrate that the average substantively explained variance of the indicators is 0.705 , while the average method-based variance is 0.015 . The ratio of substantive variance to method variance is about 47:1. In addition, almost no method factor loadings (with the exception of four) were significant. Given the small magnitude and insignificance of method variance, we contend that the method is unlikely to be of serious concern for this study.

We verified relationships among constructs via structural equation modeling (SEM). For constructs with a higher-order factor structure (organizational tensions) that are formative in nature, Lee and Cadogan [73] suggested that researchers avoid developing and assessing a model containing a direct link from the antecedent variable to the aggregate endogenous variable. Therefore, we reduced the number of estimated parameters, following the partial aggregation method. Following Menguc and Auh [65] and Chin, Marcolin, and Newsted [74], this procedure involves averaging the responses of subsets of items that measure a construct, which is formed by the three indicators for organizational tensions. The measurement model has a good fit with the data, as seen in the statistics for organizational tensions (RMSEA $=0.063, \mathrm{CFI}=0.966, \mathrm{NNFI}=0.952, \mathrm{GFI}=0.923$ ). Based on these supportive findings, and in the interests of parsimony, this study aggregated the subconstructs of strategic intent, customer orientation, and personal drivers, to obtain the higher-order construct of organizational tensions.

We employed PLS to evaluate the main hypothesized relationships, as suggested by Menguc and Auh [65]. PLS is more effective than covariance-based SEM for a mixture of formative and reflective constructs. In addition, PLS is not sensitive to sample size. Figure 2 illustrates our findings, and shows that explorative capability ( $\beta=0.152, p>0.1)$ is not statistically significant, but that exploitative capability ( $\beta=0.682, p<0.001)$ significantly and positively influences organizational tensions. We do not find support for $\mathrm{H} 1 \mathrm{a}$, but $\mathrm{H} 1 \mathrm{~b}$ is supported. When the $\beta$ values are compared, exploitative capabilities have a greater contribution to organizational tensions than explorative capabilities do $(0.682>0.152)$.

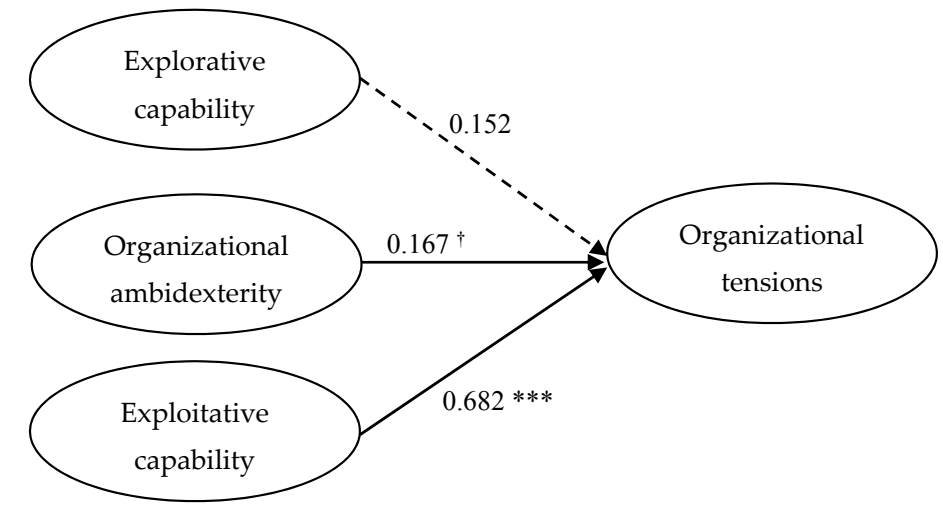

Figure 2. Standardized coefficients on partial least squares (PLS) results. $+p<0.1$; $^{*} p<0.05 ;{ }^{* *} p<0.01$; $* * * p<0.001$.

In $\mathrm{H} 2$, we posited that organizational ambidexterity would have a negative effect on organizational tensions. Figure 2 shows that the effect of the interaction between the two capabilities on organizational tensions is negative and significant $(\beta=-0.167, p<0.1)$, confirming $\mathrm{H} 2$.

\subsection{Moderation Testing}

We employed hierarchical regression to evaluate the moderation hypotheses, as suggested by Cao et al. [27], He and Wong [18], and Zhan and Chen [16]. Hierarchical regression adds controls, 
explanatory variables, and joint effect terms incrementally to gauge their contributions [18]. H3 posited that the negative effect of the interaction between organizational ambidexterity and environmental dynamism on organizational tensions would be strong. Model 3 shows that the moderating effect of the relationship between organizational ambidexterity and environmental dynamism is negatively related to organizational tensions ( $\beta=0.870, p<0.001$ ), whereas Figure 2 illustrates that the negative relationship between organizational ambidexterity and tensions is significantly stronger when environmental dynamism is high, than when it is low. The results in Table 3 and Figure 3 provide support for H3. In addition, when we put the ambidexterity of the two capabilities and the moderating effect of environmental dynamism into Models 2 and 3, and compare the results with those for Model 1, the positive contribution of exploitative capabilities to organizational tensions is stronger, compared to the positive contribution of explorative capabilities. Furthermore, the latter is not significant in Models 1-3.

Table 3. Results of regression.

\begin{tabular}{|c|c|c|c|}
\hline \multirow[b]{2}{*}{ Variables } & \multicolumn{3}{|c|}{ Organizational Tensions } \\
\hline & Model 1 & Model 2 & Model 3 \\
\hline \multicolumn{4}{|l|}{ Control variables } \\
\hline Firm size & $0.245^{* *}$ & $0.229 * *$ & $0.239 * *$ \\
\hline Firm age & 0.099 & 0.082 & 0.070 \\
\hline \multicolumn{4}{|l|}{ Independent variables } \\
\hline Explorative capability & -0.047 & -0.018 & -0.110 \\
\hline Exploitative capability & $0.270 * * *$ & $0.366^{* * *}$ & $0.470^{* * *}$ \\
\hline Environmental dynamism & & & $0.526 * * *$ \\
\hline \multicolumn{4}{|l|}{ Interaction } \\
\hline Ambidexterity & & $-0.288 * * *$ & $-0.398^{* * *}$ \\
\hline Ambidexterity ${ }^{*}$ Environmental dynamism & & & $-0.870 * * *$ \\
\hline F-value & $10.381 * * *$ & $12.005^{* * *}$ & $11.986^{* * *}$ \\
\hline R2 & 0.262 & 0.332 & 0.368 \\
\hline Adj-R2 & 0.237 & 0.304 & 0.337 \\
\hline
\end{tabular}

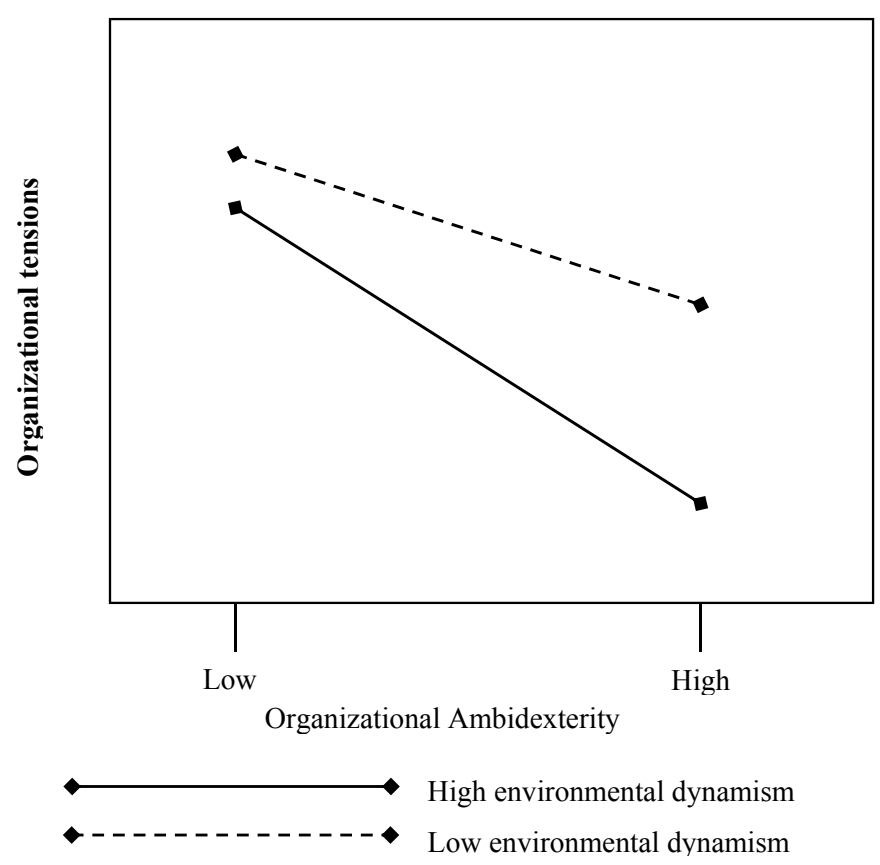

Figure 3. Moderating role of environmental dynamism on the relationship between organizational ambidexterity and tensions. 


\section{Discussion}

This study aims to investigate the degree to which an organization's emphasis on and allocation of resources to explorative and exploitative capabilities influences organizational tensions. The results suggest that balancing the contradictory tensions is important, although tensions between explorative and exploitative capabilities also exist. Accordingly, simultaneous development of the two capabilities fits well with the concept of ambidexterity.

\subsection{Theoretical Implications}

This study has important theoretical contributions to the DC literature. Besides proposing a definition of the "dark side" of DCs, this study attempts to interpret this dark side from a tensions-based view. Previous studies have argued that firms assess their valuable organizational capabilities to obtain superior performance or competitive advantages [12,15]; however, few studies have analyzed the impact of DCs on organizational tensions from dark-side issues, especially regarding the exploitative and explorative capabilities of high-tech firms. This study offers theoretical insights and empirical evidence grounded in the tension-based view [20] and the concept of DCs. However, the positive relation between exploitative capabilities and organizational tensions indicates that the results of the study coincide with the opinions of Fang et al. [17]; that is, moderate tension can help organizations grow from their mistakes. If the tension can be resolved in the foreseeable future, organizations can accumulate the knowledge to solve problems [21]; on the contrary, if the tension is unpredictable or difficult to change, it will impact the organization, and even lead to wrong decisions [75]. The results of this study are in line with those of prior research that has similarly explored the influence of the trade-off relationship between capabilities on organizational performance [12,18,32]. However, the difference is that this study is more focused on the significance of tension and the negative effect it generates. Therefore, when focusing on the influence of DCs on performance, considering the possible trade-off problems of organizational tensions is also necessary, because the theoretical foundation of DCs has been adopted according to a more multifaceted viewpoint, such as in relation to dark-side issues.

The construct of ambidexterity has been gaining increasing attention in academic circles, but we know little about how it may affect organizational tensions. This conclusion is consistent with findings by Fainshmidt et al. [12]. Under the influence of engaging in organizational ambidexterity, firms will realize positive growth, no matter which kinds of capabilities they add. Through the change of situation, the effect will help to reduce the negative tension caused by the trade-off between capabilities, and thus be to enhance organizational performance. Moreover, the organizational ambidexterity not only can reduce internal tensions, but also maintains the mutual support of internal capabilities, thus providing a kinetic energy with sustainable and stable development.

This study also addresses two other gaps in the DC literature. First, the negative relationship between the interaction of the two types of capabilities and organizational tensions establishes the "fit as moderating" assumption [18]. This finding indicates that concurrent development of exploitative and explorative capabilities in Taiwanese high-tech firms can achieve mutual synergy and reduce tensions caused by any imbalances between them. This is similar to Junni et al.'s [49] findings, which indicated that a combined dimension of ambidexterity is the most suitable measurement for exploring how firms leverage various capabilities better than others. Although tensions between the two capabilities can never be entirely eliminated, the most successful organizations reconcile them to a large degree, and thereby enhance their long-term competitiveness [28].

Second, most related studies have examined the moderating effect of organizational context on the relationship between organizational capabilities and performance. Meyer [76] emphasized the importance of incorporating context more explicitly to establish boundary conditions for theory and to develop managerially relevant insights [16]. This study agrees with his claim, and holds that, in addition to organizational context, environmental context has contradictory pressures for explorative and exploitative innovation $[43,49]$. This study provides support for the strong moderating effect of environmental dynamism on the relationship between organizational ambidexterity and 
organizational tensions. Our empirical results also provide support for Simsek's [77] proposition and address Junni et al.'s [49] suggestion that it is important to examine the boundary conditions of ambidexterity studies in terms of the robustness of the ambidexterity-tensions relationship in high-tech industries [27].

\subsection{Managerial Implications}

This study also provides managers with insights regarding the importance of organizational tensions. Although such firms place roughly equal emphasis on, and devote equal resources to, explorative and exploitative capabilities, they tend to emphasize exploitative capability items of efficiency and compatibility, which have been consistent areas of strength for high-tech firms. This finding indicates two implications. First, high-tech firms place greater emphasis on developing their exploitative, compared to explorative, capabilities. Second, high-tech firms must conduct continuous innovation activities. As an increasing number of high-tech firms shift from OEM to OBM strategies and establish design centers, developing explorative capabilities will be key to the success of the OBM model. Consequently, managers of firms pursuing OBM strategies should devote more resources to improving flexibility and innovation when developing explorative capabilities.

This study suggests that technology product markets are undergoing rapid development, and emphasis on improving exploitative capabilities will have little value-adding effect on performance [15]. Thus, the strengthening of explorative capabilities can enhance the added value of new products. Because of the nature of the high-tech industry, most firms are very conscious of market changes and trends, and most managers have begun to emphasize the development of explorative capabilities and R\&D expenditure. Therefore, we suggest that high-tech firms should perceive the maturity and stability of the market in relation to developing their exploitative capabilities. In more stable markets, these values or benefits are evident in numerous facets, such as achieving economies of scale, and discounts through large-scale production and purchasing, and establishing and maintaining closer relationships with suppliers and partners to obtain more innovation insight.

Another interesting finding of this study is that the positive influence of exploitative capabilities on organizational tensions will increase because of the moderating effect that exists between ambidexterity and environmental dynamics. This suggests that in the process of developing a dynamic organization, although tension, contradiction, and conflict already exist in the early stages, firms that focus on developing a single capability will be less aware of organizational tension. In the ambidextrous context, firms can perceive the differences in capabilities and adjust their ability development and resource allocation, as well as reducing the negative effects caused by organizational tensions. This suggests that top management teams should build an ambidextrous context to shape a culture or a structure that is appreciated by all internal members. In terms of ambidextrous context-building, this study suggests that enterprise managers may consider the organizational structure and fully assess the efficiency of management to avoid artificially expanding the range of management, and further lengthening information transmission distance. They should be committed to reducing the operation coordination procedures and strengthening quick response and information diffusion. The establishment of the "structural mechanism" is helpful for the company to shape the dual-structural organization, and can endow the organization with the ability to deal with knowledge integration and management problems caused by internal complexity and diversity, thereby encouraging the organization to identify valuable knowledge and combine relevant information.

Furthermore, our study suggests that within dynamically competitive environments, high-tech firms should aim to develop ambidexterity that pursues explorative and exploitative capabilities simultaneously. For the technology- and export-intensive high-tech manufacturing sector, the market competition such firms confront has shifted from weak to strong, and from single-market to multimarket competition. Thus, this study suggests that high-tech firms should continually facilitate market-oriented sense toward customer demands and competitors' strategies, to avoid unnecessary resource investment 
into capabilities development. They must painstakingly learn, adapt, and develop new capabilities regarding brands, innovation, distribution, human capital, and social capital, among others.

\subsection{Further Research and Limitations}

This study is not without limitations, which should prompt further research. First, because of the cross-sectional nature of the study, we were unable to test whether firms follow a sequential strategy in which they cascade their exploration into exploitation, or vice versa. To conduct such tests, future studies can employ longitudinal data with the unit of analysis being at the cross-departmental level. Second, we focused on selected constructs to develop our research framework. Although this strategy helped us maintain conceptual clarity and parsimony, we may have overlooked other variables. We encourage more research on the organizational, interfirm, and environmental determinants of organizational ambidexterity. Third, we did not undertake a thorough consideration of how to avoid common method variance when issuing questionnaires, and future studies should try to be more careful in this regard. The possible existence of common method variance in our study, and the problems arising from it, will have affected the results of the statistical analysis, as well as the process and results of methods and verification. Thus, issues related to, and verification of, common method variance, should be considered in future works.

Author Contributions: M.Y.-P.P. designed the research framework and agenda. He also wrote Introduction and Literature Review sections and analyzed data. K.-H.L. contributed to data collection and Discussion section writing.

Funding: This research received no external funding.

Conflicts of Interest: The authors declare no conflict of interest.

\section{References}

1. Chang, P.L.; Shih, H.Y. The innovation systems of Taiwan and China: A comparative analysis. Technovation 2004, 24, 529-539. [CrossRef]

2. Lai, H.C.; Shyu, J.Z. A comparison of innovation capacity at science parks across the Taiwan Strait: The case of Zhangjiang High-Tech Park and Hsinchu Science-based Industrial Park. Technovation 2005, 25, 805-813. [CrossRef]

3. Helfat, C.E.; Peteraf, M.A. Managerial cognitive capabilities and the microfoundations of dynamic capabilities. Strateg. Manag. J. 2015, 36, 831-850. [CrossRef]

4. Subramaniam, M.; Youndt, M.A. The Influence of Intellectual Capital on the Types of Innovative Capabilities. Acad. Manag. J. 2005, 48, 450-463. [CrossRef]

5. Zollo, M.; Winter, S.G. Deliberate Learning and the Evolution of Dynamic Capabilities. Organ. Sci. 2002, 13, 339-351. [CrossRef]

6. Cannone, G.; Ughetto, E. Born globals: A cross-country survey on high-tech start-ups. Int. Bus. Rev. 2014, 23, 272-283. [CrossRef]

7. Teece, D.; Pisano, G. The Dynamic Capabilities of Firms: An Introduction. Ind. Corp. Chang. 1994, 3, 537-556. [CrossRef]

8. Teece, D.J.; Pisano, G.; Shuen, A. Dynamic capabilities and strategic management. Strateg. Manag. J. 2015, 18, 25. [CrossRef]

9. Wu, L.Y. Entrepreneurial resources, dynamic capabilities and start-up performance of Taiwan's high-tech firms. J. Bus. Res. 2007, 60, 549-555. [CrossRef]

10. Zott, C. Dynamic capabilities and the emergence of intraindustry differential firm performance: Insights from a simulation study. Strateg. Manag. J. 2003, 24, 97-125. [CrossRef]

11. O'Reilly, C.A.; Tushman, M. Ambidexterity as a Dynamic Capability: Resolving the Innovator's Dilemma. Res. Organ. Behav. 2008, 28, 185-206. [CrossRef]

12. Fainshmidt, S.; Pezeshkan, A.; Lance Frazier, M.; Nair, A.; Markowski, E. Dynamic Capabilities and Organizational Performance: A Meta-Analytic Evaluation and Extension. J. Manag. Stud. 2016, 53, 1348-1380. [CrossRef] 
13. Piao, M.; Zajac, E.J. How exploitation impedes and impels exploration: Theory and evidence. Strateg. Manag. J. 2016, 37, 1431-1447. [CrossRef]

14. Prange, C.; Verdier, S. Dynamic capabilities, internationalization processes and performance. J. World Bus. 2011, 46, 126-133. [CrossRef]

15. Tushman, M.L.; O’Reilly, C.A. Winning through Innovation: A Practical Guide to Managing Organizational Change and Renewal; Harvard Business School Press: Cambridge, MA, USA, 1996.

16. Zhan, W.; Chen, R.R. Dynamic capability and IJV performance: The effect of exploitation and exploration capabilities. Asia Pac. J. Manag. 2013, 30, 601-632. [CrossRef]

17. Fang, S.R.; Chang, Y.S.; Peng, Y.C. Dark side of relationships: A tensions-based view. Ind. Mark. Manag. 2011, 40, 774-784. [CrossRef]

18. He, Z.L.; Wong, P.K. Exploration vs. exploitation: An empirical test of the ambidexterity hypothesis. Organ. Sci. 2004, 15, 481-494. [CrossRef]

19. Kristal, M.M.; Huang, X.; Roth, A.V. The effect of an ambidextrous supply chain strategy on combinative competitive capabilities and business performance. J. Oper. Manag. 2010, 28, 415-429. [CrossRef]

20. Das, T.K.; Teng, B.S. Instabilities of strategic alliances: An internal tensions perspective. Organ. Sci. 2000, 11, 77-101. [CrossRef]

21. Oláh, J.; Kovács, S.; Virglerova, Z.; Lakner, Z.; Kovacova, M.; Popp, J. Analysis and Comparison of Economic and Financial Risk Sources in SMEs of the Visegrad Group and Serbia. Sustainability 2019, 11, 1853. [CrossRef]

22. Rahmandad, H. Impact of growth opportunities and competition on firm-level capability development trade-offs. Organ. Sci. 2012, 23, 138-154. [CrossRef]

23. Winter, S. Understanding Dynamic Capabilities. Strateg. Manag. J. 2003, 24, 991-995. [CrossRef]

24. Tushman, M.L.; O’Reilly, C.A. Ambidextrous organizations: Managing evolutionary and revolutionary change. Calif. Manag. Rev. 1996, 38, 8-29. [CrossRef]

25. Atuahene-Gima, K. Resolving the capability-Rigidity paradox in new product innovation. J. Mark. 2005, 69, 61-83. [CrossRef]

26. Auh, S.; Menguc, B. Balancing exploration and exploitation: The moderating role of competitive intensity. J. Bus. Res. 2005, 58, 1652-1661. [CrossRef]

27. Cao, Q.; Gedajlovic, E.; Zhang, H. Unpacking organizational ambidexterity: Dimensions, contingencies, and synergistic effects. Organ. Sci. 2009, 20, 781-796. [CrossRef]

28. Gibson, C.B.; Birkinshaw, J. The antecedents, consequences, and mediating role of organizational ambidexterity. Acad. Manag. J. 2004, 47, 209-226. [CrossRef]

29. Gulati, R.; Puranam, P. Renewal through reorganization: The value of inconsistencies between formal and informal organization. Organ. Sci. 2009, 20, 422-440. [CrossRef]

30. Jansen, J.J.; George, G.; Van den Bosch, F.A.; Volberda, H.W. Senior team attributes and organizational ambidexterity: The moderating role of transformational leadership. J. Manag. Stud. 2008, 45, 982-1007. [CrossRef]

31. Jansen, J.J.; Volberda, H.W.; Van Den Bosch, F.A. Exploratory innovation, exploitative innovation, and ambidexterity: The impact of environmental and organizational antecedents. Schmalenbach Bus. Rev. 2005, 57, 351-363. [CrossRef]

32. Lubatkin, M.H.; Simsek, Z.; Ling, Y.; Veiga, J.F. Ambidexterity and performance in small-to medium-sized firms: The pivotal role of top management team behavioral integration. J. Manag. 2006, 32, 646-672. [CrossRef]

33. Smith, W.K.; Tushman, M.L. Managing strategic contradictions: A top management model for managing innovation streams. Organ. Sci. 2005, 16, 522-536. [CrossRef]

34. Gupta, A.K.; Smith, K.G.; Shalley, C.E. The interplay between exploration and exploitation. Acad. Manag. J. 2006, 49, 693-706. [CrossRef]

35. Koryak, O.; Lockett, A.; Hayton, J.; Nicolaou, N.; Mole, K. Disentangling the antecedents of ambidexterity: Exploration and exploitation. Res. Policy 2018, 47, 413-427. [CrossRef]

36. Yang, T.T.; Li, C.R. Competence exploration and exploitation in new product development: The moderating effects of environmental dynamism and competitiveness. Manag. Decis. 2011, 49, 1444-1470. [CrossRef]

37. Huang, S.; Ding, D.; Chen, Z. Entrepreneurial leadership and performance in Chinese new ventures: A moderated mediation model of exploratory innovation, exploitative innovation and environmental dynamism. Creat. Innov. Manag. 2014, 23, 453-471. [CrossRef] 
38. Morgan, N.A.; Zou, S.; Vorhies, D.W.; Katsikeas, C.S. Experiential and informational knowledge, architectural marketing capabilities, and the adaptive performance of export ventures: A cross-national study. Decis. Sci. 2003, 34, 287-321. [CrossRef]

39. Schreyögg, G.; Kliesch-Eberl, M. How dynamic can organizational capabilities be? Towards a dual-process model of capability dynamization. Strateg. Manag. J. 2007, 28, 913-933. [CrossRef]

40. Wang, C.L.; Ahmed, P.K. Dynamic capabilities: A review and research agenda. Int. J. Manag. Rev. 2007, 9, 31-51. [CrossRef]

41. Chen, J.; Jiao, H.; Zhao, X. A knowledge-based theory of the firm: Managing innovation in biotechnology. Chin. Manag. Stud. 2016, 10, 41-58. [CrossRef]

42. SBotella-Carrubi, M.D.; González-Cruz, T.F. Context as a Provider of Key Resources for Succession: A Case Study of Sustainable Family Firms. Sustainability 2019, 11, 1873. [CrossRef]

43. Li, S.; Han, S.; Shen, T. How Can a Firm Innovate When Embedded in a Cluster?-Evidence from the Automobile Industrial Cluster in China. Sustainability 2019, 11, 1837. [CrossRef]

44. Rothaermel, F.T.; Alexandre, M.T. Ambidexterity in technology sourcing: The moderating role of absorptive capacity. Organ. Sci. 2009, 20, 759-780. [CrossRef]

45. Raisch, S.; Birkinshaw, J.; Probst, G.; Tushman, M.L. Organizational ambidexterity: Balancing exploitation and exploration for sustained performance. Organ. Sci. 2009, 20, 685-695. [CrossRef]

46. Andriopoulos, C.; Lewis, M.W. Exploitation-exploration tensions and organizational ambidexterity: Managing paradoxes of innovation. Organ. Sci. 2009, 20, 696-717. [CrossRef]

47. Miner, A.S.; Bassof, P.; Moorman, C. Organizational improvisation and learning: A field study. Adm. Sci. Q. 2001, 46, 304-337. [CrossRef]

48. Lu, L.; Kao, S.F.; Chang, T.T.; Wu, H.P.; Cooper, C.L. Work/family demands, work flexibility, work/family conflict, and their consequences at work: A national probability sample in Taiwan. Int. J. Stress Manag. 2008, 15, 1-21. [CrossRef]

49. Junni, P.; Sarala, R.M.; Taras, V.; Tarba, S.Y. Organizational ambidexterity and performance: A meta-analysis. Acad. Manag. Perspect. 2013, 27, 299-312. [CrossRef]

50. Joshi, A.W. When does customer orientation hinder (help) radical product innovation? The role of organizational rewards. J. Prod. Innov. Manag. 2016, 33, 435-454. [CrossRef]

51. Yarimoglu, E.K. A review on dimensions of service quality models. J. Mark. Manag. 2014, 2, 79-93.

52. Slater, S.F.; Hult, G.T.M.; Olson, E.M. On the importance of matching strategic behavior and target market selection to business strategy in high-tech markets. J. Acad. Mark. Sci. 2007, 35, 5-17. [CrossRef]

53. Benner, M.J.; Tushman, M.L. Reflections on the 2013 Decade Award- “Exploitation, exploration, and process management: The productivity dilemma revisited" ten years later. Acad. Manag. Rev. 2015, 40, 497-514. [CrossRef]

54. Brown, J.S.; Duguid, P. Creativity versus structure: A useful tension. MIT Sloan Manag. Rev. 2001, 42, 93-94. [CrossRef]

55. Ebben, J.J.; Johnson, A.C. Efficiency, flexibility, or both? Evidence linking strategy to performance in small firms. Strateg. Manag. J. 2005, 26, 1249-1259. [CrossRef]

56. Knott, A.M.; Posen, H.E. Is failure good? Strateg. Manag. J. 2005, 26, 617-641. [CrossRef]

57. Mauzy, J.; Harriman, R.A. Three climates for creativity. Res. Technol. Manag. 2003, 46, 27-30. [CrossRef]

58. Elia, G.; Li, X.; Margherita, A.; Petti, C. Human-oriented corporate entrepreneurship: An integrative framework of creativity and HRM enablers. Eur. Bus. Rev. 2017, 29, 386-401. [CrossRef]

59. Ho, Y.C.; Fang, H.C.; Lin, J.F. Technological and design capabilities: Is ambidexterity possible? Manag. Decis. 2011, 49, 208-225. [CrossRef]

60. Mpinganjira, M.; Roberts-Lombard, M.; Svensson, G. Validating the relationship between trust, commitment, economic and non-economic satisfaction in South African buyer-supplier relationships. J. Bus. Ind. Mark. 2017, 32, 421-431. [CrossRef]

61. Garg, S.; Eisenhardt, K.M. Unpacking the CEO-Board Relationship: How Strategy Making Happens in Entrepreneurial Firms. Acad. Manag. J. 2017, 60, 1828-1858. [CrossRef]

62. Schilke, O. On the contingent value of dynamic capabilities for competitive advantage: The nonlinear moderating effect of environmental dynamism. Strateg. Manag. J. 2014, 35, 179-203. [CrossRef]

63. Lin, Z.; Yang, H.; Demirkan, I. The performance consequences of ambidexterity in strategic alliance formations: Empirical investigation and computational theorizing. Manag. Sci. 2007, 53, 1645-1658. [CrossRef] 
64. Stump, R.L.; Heide, J.B. Controlling supplier opportunism in industrial relationships. J. Mark. Res. 1996, 33, 431-441. [CrossRef]

65. Menguc, B.; Auh, S. The asymmetric role of market orientation on the ambidexterity firm performance relationship for prospectors and defenders. Ind. Mark. Manag. 2008, 37, 455-470. [CrossRef]

66. Hox, J.J.; Moerbeek, M.; van de Schoot, R. Multilevel Analysis: Techniques and Applications, 3rd ed.; Routledge: Abingdon-on-Thames, UK, 2017.

67. Groysberg, B.; Lee, L.E. Hiring stars and their colleagues: Exploration and exploitation in professional service firms. Organ. Sci. 2009, 20, 740-758. [CrossRef]

68. Stam, W.; Elfring, T. Entrepreneurial orientation and new venture performance: The moderating role of intra-and extraindustry social capital. Acad. Manag. J. 2008, 51, 97-111. [CrossRef]

69. Jaworski, B.J.; Kohli, A.K. Market Orientation: Antecedents and Consequences. J. Mark. 1993, 57, 53-70. [CrossRef]

70. Zahra, S.A.; Sapienza, H.J.; Davidsson, P. Entrepreneurship and dynamic capabilities: A review, model and research agenda. J. Manag. Stud. 2006, 43, 917-955. [CrossRef]

71. Hair, J.F.; Black, W.C.; Babin, B.J.; Anderson, R.E.; Tatham, R.L. Multivariate Data Analysis, 6th ed.; Pearson Prentice Hall: Upper Saddle River, NJ, USA, 2006.

72. Podsakfoff, P.M.; MacKenzie, S.B.; Lee, J.Y.; Podsakoff, N.P. Common Method Biases in Behavioral Research: A Critical Review of the Literature and Recommended Remedies. J. Appl. Psychol. 2003, 88, 879-903. [CrossRef]

73. Lee, N.; Cadogan, J.W. Problems with Formative and Higher-Order Reflective Variables. J. Bus. Res. 2013, 66, 242-247. [CrossRef]

74. Chin, W.W.; Barbara, L.M.; Peter, R.N. A partial least squares latent variable modelling approach for measuring interaction effects: Results from a Monte Carlo simulation study and an electronic-mail emotion/adoption study. Inf. Syst. Res. 2003, 14, 189-217. [CrossRef]

75. Anderson, E.; Jap, S.D. The dark side of close relationships. MIT Sloan Manag. Rev. 2005, 46, 75-82. [CrossRef]

76. Meyer, K.E. Contextualising organisational learning: Lyles and Salk in the context of their research. J. Int. Bus. Stud. 2007, 38, 27-37. [CrossRef]

77. Simsek, Z. Organizational ambidexterity: Towards a multilevel understanding. J. Manag. Stud. 2009, 46, 597-624. [CrossRef] 